\title{
Effect of dietary supplementation of garlic, ginger and their combination on feed intake, growth performance and economics in commercial broilers
}

V. K. Karangiya ${ }^{1}$, H. H. Savsani ${ }^{1}$, Shrikant Soma Patil ${ }^{1}$, D. D. Garg ${ }^{1}$, K. S. Murthy ${ }^{1}$, N. K. Ribadiya ${ }^{1}$ and S. J. Vekariya ${ }^{2}$

1. Department of Animal Nutrition, College of Veterinary Science and Animal House, Jungadh Agricultural University, Junagadh, Gujarat, India; 2. Department of Animal Husbandry and Extension Education, College of Veterinary Science and Animal House, Jungadh Agricultural University, Junagadh, Gujarat, India.

Corresponding author: Shrikant Soma Patil, e-mail: drsrpatt@gmail.com, VKK: vijayvet007@gmail.com,HHS: hhsavsani@jau.in, DDG: drddgarg@gmail.com, KSM: ksmrl_5860@yahoo.co.in, NKR: nkribadiya@gmail.com, SJV: vekariya2710@gmail.com

Received: 04-11-2015, Revised: 14-01-2016, Accepted: 20-01-2016, Published online: 08-03-2016

doi: 10.14202/vetworld.2016.245-250 How to cite this article: Karangiya VK, Savsani HH, Patil SS, Garg DD, Murthy KS, Ribadiya NK, Vekariya SJ (2016) Effect of dietary supplementation of garlic, ginger and their combination on feed intake, growth performance and economics in commercial broilers, Veterinary World, 9(3): 245-250.

\begin{abstract}
Aim: The present study was carried out to evaluate the effect of supplementation of garlic, ginger and their combination in the diets of broiler chickens and assessment in terms of feed intake, growth performance and economics of feeding.

Materials and Methods: A total of 240 1-day-old Cobb-400 broiler chicks were randomly assigned to four dietary treatments each with three replicates of 20 chicks per replicate $(n=60)$. Four experimental diets were formulated in such a way that control diet $\left(\mathrm{T}_{1}\right)$ contained neither ginger nor garlic. While, birds in group $\mathrm{T}_{2}$ and $\mathrm{T}_{3}$ were fed with diets containing $1 \%$ garlic and ginger, respectively. Diet 4 ( $\mathrm{T}_{4}$ group) contained a combination of $1 \%$ of garlic and ginger. The feeding experiment was carried out for 42 days, and different parameters evaluated includes feed intake, weight gain, feed conversion ratio, gut morphometry, and economics of feeding in terms of return over feed cost (ROFC) and European Performance Efficiency Index.
\end{abstract}

Results: Feed intake of experimental birds in ginger and mixture of garlic and ginger supplemented groups, i.e., $\mathrm{T}_{3}$ and $\mathrm{T}_{4}$ groups have significantly $(\mathrm{p}<0.05)$ higher feed intake as compared to control. While, feeding of garlic have non-significant effect on feed intake as compared to other groups. A body weight gain ( $g / b i r d)$ was found to be significantly ( $<<0.05)$ higher in garlic ( $\mathrm{T}_{2}$ group) and ginger ( $\mathrm{T}_{3}$ group) supplemented group as compare to control and garlic and ginger mixture supplemented group $\left(T_{4}\right.$ group). Feed conversion ratio was significantly $(\mathrm{p}<0.05)$ lower in ginger $\left(\mathrm{T}_{3}\right.$ group) supplemented group as compare to other groups. Mean villi length, villi width and cryptal depth were significantly $(p<0.05)$ higher in $\mathrm{T}_{3}$ group than rest of all three groups, indicating increased absorptive surface area. ROFC was significantly $(\mathrm{p}<0.05)$ lower in $\mathrm{T}_{3}$ and $\mathrm{T}_{4}$ groups as compare to control. However, it was not significantly different between control and $\mathrm{T}_{2}$ group.

Conclusion: On the basis of the results of the study, it is concluded that supplementation of garlic improves the performance of broilers when added at the rate of $1 \%$ of broiler ration and can be a viable alternative to antibiotic growth promoter in the feeding of broiler chicken.

Keywords: body weight, broiler chickens, feed intake, garlic, ginger.

\section{Introduction}

Feed is the major component of total costs of poultry venture as $80 \%$ of the total expenditure is on procurement of feed [1]. Feed additives are a group of nutrient and non-nutrient compounds which helps in improving the efficiency of feed utilization and thus reducing the high cost of feed. In the past, antibiotics were the most routinely used feed additives. However, nowadays use of antibiotics is not only limited but their use in livestock and poultry industry also have been banned in many countries due to the reasons like

Copyright: Karangiya, et al. Open Access. This article is distributed under the terms of the Creative Commons Attribution 4.0 International License (http://creativecommons.org/licenses/ by/4.0/), which permits unrestricted use, distribution, and reproduction in any medium, provided you give appropriate credit to the original author(s) and the source, provide a link to the Creative Commons license, and indicate if changes were made. The Creative Commons Public Domain Dedication waiver (http:// creativecommons.org/publicdomain/zero/1.0/) applies to the data made available in this article, unless otherwise stated. alteration of natural gut microbiota and drug resistance in bacteria and humans. As a result, to replace them without adversely affecting the performance of birds, natural growth promoters such as prebiotics, probiotics, synbiotics, enzymes, plant extracts, etc., can be used to feed the broilers [2].

Garlic and ginger as natural growth promoters can be potential alternatives for common artificial growth promoters like antibiotics [3]. Ginger is the rhizome of the plant Zingiber officinale, consumed as a delicacy, medicine, or spice. Preliminary research indicates that nine compounds found in ginger may bind to serotonin receptors which may influence gastrointestinal function. Research conducted in-vitro shows that ginger extract might control the quantity of free radicals and the peroxidation of lipids [4] and have anti-diabetic properties [5]. Garlic (Allium sativum) has been used as a spice and a native medicine for many years. It has possessed antibacterial, antifungal, antiparasitic, antiviral, antioxidant, 
anticholesteremic, anti-cancerous, and vasodilator characteristics [6]. Ginger and garlic supplements in broiler chicken diets have been recognized for their strong stimulating effect on the immune and digestive systems in birds [7]. Recent research works on ginger and garlic formulations as feed additives have shown encouraging results in regards to weight gain, feed efficiency, lowered mortality and increased livability in poultry birds $[8,9]$.

Different workers have tried at different levels of garlic and ginger in the diet of birds and but most consistent results were obtained at about 1\% level [10-12] and supplementation of these products beyond 1\% of ration may also have a negative effect on overall cost of feeding. As a result, they are incorporated at the level of $1 \%$ in the diet of broilers. On the other hand, studies on their use as mixtures in the diet of birds have produced inconsistent results. Therefore, this study was planned to generate more information about the effect of using garlic and ginger alone and in combination on performance and economics of supplementation in the diet broiler chickens.

\section{Materials and Methods}

\section{Ethical approval}

This research was carried out as a part of M.V.Sc. research after the approval of competent authority of the Director of research and Dean P.G. Studies, Junagadh Agricultural University, Junagadh.

\section{Location of study}

The experiment was carried out at the at modern poultry farm located at Mangrol, city of Junagadh district which lies approximately on latitude $70.12^{\prime} \mathrm{E}$ and longitude 21.12 ' $\mathrm{N}$ with an average elevation of $18 \mathrm{~m}$ (59 feet) above sea level. This region of South Saurashtra sub-zone comes under Zone-XIII of agro climatic zone of India, which includes only Junagadh district. A climate is dry sub-humid, and adverse climatic conditions prevail in this region with minimum and maximum temperature ranging from $28^{\circ} \mathrm{C}$ to $38^{\circ} \mathrm{C}$ in summer and $10^{\circ} \mathrm{C}$ to $25^{\circ} \mathrm{C}$ in winter months [13]. The average annual rainfall ranges from 1000 to $1200 \mathrm{~mm}$.

\section{Source and processing of ginger and garlic}

Groundnut ginger and garlic used in this study was bought from a local market in raw form. Then, it was cut into smaller pieces and dried sufficiently in the sunlight. After drying, required amount of ginger and garlic was prepared by fine grinding and passing through $1 \mathrm{~mm}$ sieve.

\section{Experimental birds and diets}

About 1-day-old 240 broiler chicks of cobb-400 strain with average body weight $40.00-40.28 \mathrm{~g}$ were wing banded and distributed randomly into four groups having three replicates of 20 birds each by randomized block design and allocated to four dietary treatments as $\mathrm{T}_{1}, \mathrm{~T}_{2}, \mathrm{~T}_{3}$ and $\mathrm{T}_{4}$. Experimental birds in group $\mathrm{T}_{1}$ were fed with conventional concentrate mixture while birds in $\mathrm{T}_{2}, \mathrm{~T}_{3}$, and $\mathrm{T}_{4}$ groups were fed on concentrate mixture supplemented with $1 \%$ garlic, $1 \%$ ginger and mixture of $1 \%$ garlic and $1 \%$ ginger, respectively. Ingredient compositions of these starter and finisher rations are presented in Tables-1 and 2, respectively.

\section{Feeding and management procedures}

All the experimental birds were reared in well ventilated shed in deep litter pens and kept under uniform management conditions. The reference and test concentrate mixtures and clean drinking water were supplied to the birds ad libitum throughout the study period to meet the nutrient as per BIS [14]. All the birds were weighed weekly in the morning, before feeding and watering. Feed intake was calculated by measuring the amount of feed offered and residue left after $24 \mathrm{~h}$. Feed conversion ratio was calculated by dividing the feed intake by weight gain. Vaccination and other routine poultry management practices were carried out neatly.

\section{Gut morphometry}

At the end of the experiment, two birds per replicate were randomly selected and slaughtered by decapitation to study gut morphometry. Sections of

Table-1: Ingredient and chemical composition of broiler starter feeds.

\begin{tabular}{|c|c|c|c|c|}
\hline Feed ingredient $(\mathbf{k g})$ & $T_{1}$ & $\mathbf{T}_{2}$ & $\mathbf{T}_{3}$ & $\mathbf{T}_{4}$ \\
\hline Maize & 63 & 62 & 62 & 61 \\
\hline Soybean meal & 29 & 29 & 29 & 28 \\
\hline Meat and bone meal & 3 & 3 & 3 & 3 \\
\hline Vegetable oil & 2.5 & 2.5 & 2.5 & 2.5 \\
\hline Lime stone & 1.2 & 1.2 & 1.2 & 1.2 \\
\hline Dicalcium phosphate & 0.8 & 0.8 & 0.8 & 0.8 \\
\hline Garlic & 0 & 1 & 0 & 1 \\
\hline Ginger & 0 & 0 & 1 & 1 \\
\hline Salt & 0.45 & 0.45 & 0.45 & 0.45 \\
\hline Methionine & 0.27 & 0.27 & 0.27 & 0.27 \\
\hline Lysine & 0.20 & 0.20 & 0.20 & 0.20 \\
\hline Vitamin & 0.05 & 0.05 & 0.05 & 0.05 \\
\hline Mineral mixture & 0.1 & 0.1 & 0.1 & 0.1 \\
\hline Calcium carbonate & 0.15 & 0.15 & 0.15 & 0.15 \\
\hline Liver tonic & 0.05 & 0.05 & 0.05 & 0.05 \\
\hline Total & 100.77 & 100.77 & 100.77 & 100.77 \\
\hline \multicolumn{5}{|l|}{$\begin{array}{l}\text { Chemical composition } \\
\text { (\% DM basis) }\end{array}$} \\
\hline DM & 92.45 & 92.44 & 92.66 & 93.34 \\
\hline $\mathrm{CP}$ & 23.18 & 23.30 & 23.12 & 23.24 \\
\hline $\mathrm{EE}$ & 3.36 & 3.52 & 3.40 & 3.56 \\
\hline $\mathrm{CF}$ & 4.36 & 4.61 & 4.55 & 4.20 \\
\hline NFE & 61.3 & 60.96 & 60.96 & 60.87 \\
\hline $\mathrm{TA}$ & 7.80 & 7.61 & 7.97 & 8.13 \\
\hline $\mathrm{Ca}$ & 1.11 & 1.09 & 1.09 & 1.10 \\
\hline $\mathrm{P}$ & 0.86 & 0.91 & 0.90 & 0.89 \\
\hline ME (Kcal) & 3176 & 3176 & 3176 & 3176 \\
\hline
\end{tabular}

Tracemin CB: Each $1 \mathrm{~kg}$ contain: Manganese - $90 \mathrm{~g}$, Zinc - $80 \mathrm{~g}$, Iron - $90 \mathrm{~g}$, Copper - $15 \mathrm{~g}$, Iodine - $2 \mathrm{~g}$ and Selenium - 300 mg, Vitamin (Groviplex powder): Each $100 \mathrm{~g}$ contains: Vitamin B2 - $1.25 \mathrm{~g}$, Vitamin B6 $-0.620 \mathrm{~g}$, Vitamin B12 - $6.25 \mathrm{~g}$, Nicotinamide - $18.75 \mathrm{~g}$, Lysine monohydrochloride $-10.00 \mathrm{~g}$, Choline bitartarate $-15.82 \mathrm{~g}$, Calcium pantothenate $-1.51 \mathrm{~g}$. DM=Dry matter, $\mathrm{OM}=$ Organic matter, $\mathrm{CP}=$ Crude protein, $\mathrm{CF}=$ Crude fiber, $\mathrm{NFE}=$ Nitrogen free extract, $\mathrm{ME}=$ Metabolic energy 
the jejunum were harvested and fixed in $10 \%$ formalin. Histological sections were cut and stained with hematoxylin and eosin stain. From each section, two randomly selected villi were measured in each slide per microscopic field. Two fields were used for measurement of villi lengths, widths and cryptal depths under the microscope using graduated eyepiece with a $(\times 10)$ objective lens [15]. The villus height was measured from the tip of the villus to the villus-crypt junction. The villus width was defined as the distance from the outside epithelial edge to the outside of the opposite epithelial edge along a line passing through the vertical midpoint of the villus. The crypt depth was defined as the depth of the invagination between adjacent villi [16].

\section{Return over feed cost (ROFC)}

It is calculated by subtracting the total feed cost from the income from the sold bird on live weight basis during from rearing period of 42-day. While, European Performance Efficiency Index (EPEI) was calculated by following formula [17]:

$$
\text { EPEI }=\frac{\text { Average bodyweight }(\mathrm{g}) \times \text { Livability }(\%)}{\text { Age of flock }(\text { days }) \times \mathrm{FCR}} \div 10
$$

Table-2: Ingredient and chemical composition of broiler finisher feeds.

\begin{tabular}{lcccc}
\hline Feed ingredient (kg) & $\mathbf{T}_{\mathbf{1}}$ & $\mathbf{T}_{\mathbf{2}}$ & $\mathbf{T}_{\mathbf{3}}$ & $\mathbf{T}_{\mathbf{4}}$ \\
\hline Maize & 65 & 64 & 64 & 64 \\
Soybean meal & 25 & 25 & 25 & 24 \\
Meat and bone meal & 3 & 3 & 3 & 3 \\
Vegetable oil & 4 & 4 & 4 & 4 \\
Lime stone & 1.1 & 1.1 & 1.1 & 1.1 \\
Dicalcium phosphate & 0.8 & 0.8 & 0.8 & 0.8 \\
Garlic & 0 & 1 & 0 & 1 \\
Ginger & 0 & 0 & 1 & 1 \\
Salt & 0.45 & 0.45 & 0.45 & 0.45 \\
Methionine & 0.25 & 0.25 & 0.25 & 0.25 \\
Lysine & 0.15 & 0.15 & 0.15 & 0.15 \\
Vitamin & 0.05 & 0.05 & 0.05 & 0.05 \\
Mineral mixture & 0.1 & 0.1 & 0.1 & 0.1 \\
Calcium carbonate & 0.15 & 0.15 & 0.15 & 0.15 \\
Liver tonic & 0.05 & 0.05 & 0.05 & 0.05 \\
Total & 100.10 & 100.10 & 100.10 & 100.10 \\
Chemical composition & & & & \\
(\% DM basis) & & & & \\
DM & 92.22 & 92.25 & 92.24 & 92.51 \\
CP & 20.15 & 20.27 & 20.19 & 20.28 \\
EE & 3.27 & 3.40 & 3.36 & 3.47 \\
CF & 4.43 & 4.45 & 4.53 & 4.74 \\
NFE & 62.84 & 62.79 & 63.02 & 62.94 \\
TA & 9.31 & 9.09 & 8.90 & 8.57 \\
Ca & 1.16 & 1.14 & 1.17 & 1.14 \\
P & 0.97 & 0.96 & 0.99 & 0.90 \\
ME (Kcal) & 3281 & 3281 & 3281 & 3281 \\
\hline Tracemin CB: Each $1 \mathrm{~kg}$ & & & & \\
& & & &
\end{tabular}

Tracemin CB: Each $1 \mathrm{~kg}$ contain: Manganese - $90 \mathrm{~g}$, Zinc - $80 \mathrm{~g}$, Iron - $90 \mathrm{~g}$, Copper - $15 \mathrm{~g}$, Iodine - $2 \mathrm{~g}$ and Selenium - 300 mg, Vitamin (Groviplex powder): Each $100 \mathrm{~g}$ contains: Vitamin B2 $-1.25 \mathrm{~g}$, Vitamin B6 $-0.620 \mathrm{~g}$, Vitamin B12 - $6.25 \mathrm{~g}$, Nicotinamide - $18.75 \mathrm{~g}$, Lysine monohydrochloride - $10.00 \mathrm{~g}$, Choline bitartarate - $15.82 \mathrm{~g}$, Calcium pantothenate $-1.51 \mathrm{~g}$. DM=Dry matter, $\mathrm{OM}=$ Organic matter, $\mathrm{CP}=$ Crude protein, $\mathrm{CF}=$ Crude fiber, $\mathrm{NFE}=$ Nitrogen free extract, $\mathrm{ME}=$ Metabolic energy

\section{Chemical and statistical analysis}

Samples of feeds were milled to pass through a $1 \mathrm{~mm}$ sieve and then analyzed following the methods of AOAC [18] to determine dry matter by the oven drying method (934.01), organic matter by muffle furnace incineration $(967.05)$, crude protein by Kjeldahl method (984.13) $(\mathrm{N} \times 6.25)$, ether extract (920.39), ash (942.05). The data collected on various parameters were analyzed using the method of Snedecor and Cochran [19].

\section{Results and Discussion}

\section{Nutrient composition of experimental rations}

Nutrient composition of different concentrate mixtures is given in Tables-1 and 2. All the feeds were found to be isonitrogenous and comparable with respect to their proximate composition.

\section{Feed intake (g/bird)}

Average total feed intake of experimental birds in $\mathrm{T}_{3}$ and $\mathrm{T}_{4}$ groups was significantly $(\mathrm{p}<0.05)$ higher as compared to $T_{1}$ and garlic supplemented $T_{2}$ group (Table-3). However, feed intake in $\mathrm{T}_{1}$ and $\mathrm{T}_{2}$ was similar and did not differ significantly. It has shown that there is no adverse effect of smell and/or taste of garlic and ginger on the palatability of feed in the diets of broilers.

The results are in agreement with different workers who has that reported that ginger powder in the broiler's diets had a significant positive effect on feed consumption [20,21]. Similarly, different workers have reported non-significant effect of garlic supplementation on feed intake in broilers [22-24].

\section{Body weight gain $(\mathrm{g})$ and feed conversion ratio}

Total body weight gain (g) of experimental birds supplemented with garlic $\left(\mathrm{T}_{2}\right)$ and ginger $\left(\mathrm{T}_{3}\right)$ showed significantly $(\mathrm{p}<0.05)$ higher values as compared to control and combination of garlic and ginger $\left(\mathrm{T}_{4}\right)$ supplemented group (Table-3). Whereas, non-significant difference was observed between $T_{1}$ and $T_{4}$ groups. The improvement in weight gain of experimental birds fed with garlic powder may be due to the action of compounds like allicin and oregano sulfur compound responsible for inhibition of pathogenic bacteria and fungi results into the improved gut environment [25]. Improvement in body weight gain of

Table-3: Proximate composition of garlic and ginger (on \% DMB).

\begin{tabular}{lcc}
\hline Particulars & Garlic & Ginger \\
\hline DM & 85.25 & 87.39 \\
OM & 74.64 & 76.69 \\
CP & 7.41 & 5.85 \\
CF & 1.83 & 2.93 \\
EE & 2.41 & 1.35 \\
NFE & 85.81 & 87.58 \\
Total ash & 2.54 & 2.29 \\
\hline
\end{tabular}

$\mathrm{EE}=\mathrm{Ether}$ extract, $\mathrm{DM}=$ Dry matter, $\mathrm{OM}=$ Organic matter, $\mathrm{CP}=$ Crude protein, $\mathrm{CF}=$ Crude fiber, $\mathrm{NFE}=$ Nitrogen free extract, DBM=Diamondback moth 
broiler chicks fed on ginger might be due to the active components present in the ginger which stimulates digestive enzymes and improves overall digestion and thus leads to increased body weight gain. It has been established fact that ginger in the diets stimulate lactic acid bacteria and decreases pathogenic bacteria such as mesophilic aerobic, coliform and Escherichia coli and thus improves absorption of nutrients leads to better weight gain of the birds [26]. The results are consistent with those of Mohamed et al., Sadeghi et al., Arshad et al. $[21,27,28]$ who stated that use of ginger to the diet of broilers had a significant $(\mathrm{p}<0.05)$ positive effect on the body weight gain as compared to the control.

Experimental birds in $\mathrm{T}_{4}$ group showed significantly $(p<0.05)$ higher average FCR as compare to $\mathrm{T}_{1}, \mathrm{~T}_{2}$ and $\mathrm{T}_{3}$ groups (Table-3). The supplementation of garlic and ginger fed alone in the diet of birds does not exert any significant effect on FCR as compared to control. Although, better FCR was observed in $\mathrm{T}_{3}$ group followed by $T_{2}$ and $T_{1}$ groups. These results are in accordance with the findings of Aji et al., Mansoub and Nezhady [23,29] who has reported non-significant effect of garlic on FCR. These results are also in agreement with Ademola et al., Thayalini et al. [30,31] who did not observe any significant improvements in the feed conversion ratio of broilers fed on a diet containing ginger powder as compared to the control group.

\section{Gut morphometry}

The statistical analysis of the morphometry of the jejunum showed that values of mean villi length and width were significantly $(\mathrm{p}<0.05)$ higher in $\mathrm{T}_{3}$ group (Table-4). This represents an increase in the absorptive surface area of the intestine and thus an increased absorptive capacity resulting higher body weight gain and lower FCR in ginger supplemented group. Same was true for cryptal depth in treatment group $\mathrm{T}_{3}$, and it was significantly $(p<0.05)$ higher compare to other groups. Since crypt cells are responsible for secretion of electrolytes which enhance water secretion into the intestinal lumen for the purpose of digestion, it could be inferred that digestibility of nutrient was enhanced in $\mathrm{T}_{3}$ group.

Stem cells at the base of crypts are known to be the source of all the cells which lines the crypt and the villi. Thus, a higher cryptal depth observed in $\mathrm{T}_{3}$ is an indication of a higher mucosal proliferation activity for more efficient digestibility and absorption of ingested feed in this group. This study shows that ginger has ability to increase the digestive and absorptive capacity of the small intestine of commercial broilers by increasing the cryptal depth as well as the absorptive surface area of the intestine i.e.. villi length and width. These finding are in agreement with those of Oladele et al. [32] who stated that an increase in the absorptive capacity of intestine might be due to increase absorptive surface area which results in higher body weight gain and lower FCR of broiler birds.

\section{ROFC}

Average ROFC in terms of (Rs./bird), income from selling of birds and feed cost of broilers under different treatment groups has been shown in Table-5. The cost of feed per kg for different treatment groups in respect to starter and finisher phases is shown in Table-6. The income from selling of the birds was significantly $(\mathrm{p}<0.05)$ higher in $\mathrm{T}_{3}$ group than the control group, but there was a non-significant difference between other supplemented groups. Feed cost during whole experimental period was significantly $(p<0.05)$ higher in $\mathrm{T}_{3}$ and $\mathrm{T}_{4}$ group than control. While, it was non-significant for control and $\mathrm{T}_{2}$ group. ROFC was significantly $(\mathrm{p}<0.05)$ lower in $\mathrm{T}_{3}$ and $\mathrm{T}_{4}$ groups as compare to control. However, it was not significantly

Table-4: Performance of experimental birds.

\begin{tabular}{lcccccc}
\hline Particulars & \multicolumn{3}{c}{ Treatments } & SEM & p value \\
\cline { 2 - 5 } & $\mathbf{T}_{\mathbf{1}}$ & $\mathbf{T}_{\mathbf{2}}$ & $\mathbf{T}_{\mathbf{3}}$ & $\mathbf{T}_{\mathbf{4}}$ & & \\
\hline Initial body weight $(\mathrm{g})$ & 40.10 & 40.00 & 40.02 & 40.12 & 0.04 & $\mathrm{NS}$ \\
Final body weight $(\mathrm{g})$ & $1646.68^{\mathrm{c}}$ & $1689.32^{\mathrm{b}}$ & $1758.89^{\mathrm{a}}$ & $1638.26^{\mathrm{c}}$ & 13.63 & $\mathrm{p}<0.05$ \\
Average final body weight gain $(\mathrm{g})$ & $1606.7^{\mathrm{c}}$ & $1649.17^{\mathrm{b}}$ & $1724.17^{\mathrm{a}}$ & $1598.36^{\mathrm{c}}$ & 28.76 & $\mathrm{p}<0.05$ \\
Average weekly weight gain $(\mathrm{g})$ & 267.76 & $274.88^{\mathrm{a}}$ & 286.20 & 266.34 & 7.7 & $\mathrm{NS}$ \\
Average total feed intake & $3270.56^{\mathrm{b}}$ & $3259.12^{\mathrm{b}}$ & $3367.77^{\mathrm{a}}$ & $3395.61^{\mathrm{a}}$ & 34.28 & $\mathrm{p}<0.05$ \\
Feed conversion ratio & $1.90^{\mathrm{b}}$ & $1.87^{\mathrm{b}}$ & $1.84^{\mathrm{b}}$ & $1.99^{\mathrm{a}}$ & 0.03 & $\mathrm{p}<0.05$ \\
\hline
\end{tabular}

Means within row with different superscript differ significantly $(p<0.05)$. NS=Non-significant, SEM=Standard error of mean

Table-5: Gut morphometry of experimental birds.

\begin{tabular}{lccccc}
\hline Particulars & \multicolumn{3}{c}{ Treatments } & P value \\
\cline { 2 - 5 } & $\mathbf{T}_{\mathbf{1}}$ & $\mathbf{T}_{\mathbf{2}}$ & $\mathbf{T}_{\mathbf{3}}$ & $\mathbf{T}_{\mathbf{4}}$ & \\
\hline Villi length & $25.6 \pm 2.0^{\mathrm{c}}$ & $27.8 \pm 2.9^{\mathrm{b}}$ & $39.3 \pm 2.3^{\mathrm{a}}$ & $27.4 \pm 1.8^{\mathrm{b}}$ & $\mathrm{p}<0.05$ \\
Villi width & $6.02 \pm 1.1^{\mathrm{b}}$ & $5.76 \pm 1.1^{\mathrm{b}}$ & $7.64 \pm 1.6^{\mathrm{a}}$ & $7.60 \pm 1.5^{\mathrm{a}}$ & $\mathrm{p}<0.05$ \\
Cryptal depth & $11.1 \pm 1.1^{\mathrm{c}}$ & $21.3 \pm 2.1^{\mathrm{a}}$ & $23.0 \pm 1.6^{\mathrm{a}}$ & $13.7 \pm 4.3^{\mathrm{b}}$ & $\mathrm{p}<0.05$ \\
Villus height: Cryptal depth & 2.30 & 1.31 & 1.71 & 2.0 & \\
\hline
\end{tabular}

All regions, absolute units, lengths $\times 10 \mu \mathrm{m}$. Means within row with different superscript differ significantly $(p<0.05)$

Veterinary World, EISSN: 2231-0916 
Table-6: The ROFC (Rs./bird) realized under different feed supplement groups.

\begin{tabular}{|c|c|c|c|c|c|}
\hline Particulars & $\mathbf{T}_{1}$ & $\mathbf{T}_{2}$ & $\mathbf{T}_{3}$ & $\mathbf{T}_{4}$ & p-value \\
\hline Income from bird sold (Rs./bird) & $107.25 \pm 2.25^{b}$ & $109.84 \pm 2.37^{\mathrm{b}}$ & $114.39 \pm 2.05^{a}$ & $106.60 \pm 1.82^{b}$ & $p<0.05$ \\
\hline Feed cost (Rs./bird) & $83.80 \pm 1.44^{b}$ & $87.36 \pm 1.28^{\mathrm{b}}$ & $99.03 \pm 0.88^{a}$ & $104.8 \pm 1.16^{a}$ & $p<0.05$ \\
\hline ROFC (Rs./bird) & $23.45 \pm 1.23^{a}$ & $22.48 \pm 1.18^{a}$ & $15.36 \pm 0.82^{b}$ & $1.80 \pm 0.08^{c}$ & $p<0.05$ \\
\hline ROFC (Rs./kg live weight) & 14.21 & 13.30 & 8.72 & 1.09 & \\
\hline
\end{tabular}

*Means within row with different superscript differ significantly $(p<0.05)$. ROFC $=$ Return over feed cost

Table-7: Cost of feeds under different feed supplement groups.

\begin{tabular}{lcccc}
\hline Type of feed & $\mathbf{T}_{\mathbf{1}}$ & $\mathbf{T}_{\mathbf{2}}$ & $\mathbf{T}_{\mathbf{3}}$ & $\mathbf{T}_{\mathbf{4}}$ \\
\hline Broiler starter (Rs./kg) & 25.56 & 27.06 & 29.56 & 31.06 \\
Broiler finisher (Rs./kg) & 25.22 & 26.72 & 29.22 & 30.72 \\
\hline
\end{tabular}

Table-8: EPEI of broilers fed with garlic, ginger and their combination under different treatment.

\begin{tabular}{|c|c|c|c|c|c|}
\hline \multirow[t]{2}{*}{ Particulars } & \multicolumn{4}{|c|}{ Treatments } & \multirow[t]{2}{*}{ p value } \\
\hline & $\mathbf{T}_{1}$ & $\mathbf{T}_{2}$ & $\mathbf{T}_{3}$ & $\mathbf{T}_{4}$ & \\
\hline EPEI & $192.98 \pm 4.28^{c}$ & $211.58 \pm 5.36^{\mathrm{b}}$ & $223.94 \pm 6.22^{\mathrm{a}}$ & $196.22 \pm 4.92^{c}$ & $p<0.05$ \\
\hline
\end{tabular}

Means within row with different superscript differ significantly $(p<0.05)$. EPEI=European performance efficiency index

different between control and $\mathrm{T}_{2}$ group. ROFC (Rs./kg live weight) was highest in $\mathrm{T}_{1}(14.21 \%)$ then $\mathrm{T}_{2}(13.30 \%)$ followed by $\mathrm{T} 3(8.72 \%)$ and $\mathrm{T}_{4}(1.09 \%)$ suggesting comparable returns of $1 \%$ garlic with control. However, due to the higher cost of ginger, rate over feed cost is diminishing in other two groups. It indicated that ginger did not show any negative or positive effect in ROFC. The present study was in accordance with Mohammed and Yusuf [33] who has found no differences in cost of feed per $\mathrm{kg}$ gain for broilers on dietary supplementation of ginger.

\section{EPEI}

The EPEI for performance of the broilers is given in Tables-7 and 8 . The EPEI value was higher in $\mathrm{T}_{3}$ (223.94) which was followed by $\mathrm{T}_{2}$ (211.58), $\mathrm{T}_{4}$ (196.22) and $\mathrm{T}_{1}$ (192.98). EPEI value was significantly $(\mathrm{p}<0.05)$ higher in $\mathrm{T}_{3}$ and $\mathrm{T}_{2}$ groups than the control group. While, there was a non-significant difference between $T_{1}$ and $T_{2}$ group. The higher EPEI value corresponds to higher average body weight; superior livability and higher feed conversion ratio in a stipulated period of experimental trial and thus indicates overall economics feeding in birds [34]. Hence, on the basis of EPEI, it can be stated that supplementation of ginger in the diet of birds was found to be more economical than other groups.

\section{Conclusion}

At the end of the experiment, on the basis of the performance of broilers in respect to feed intake, body weight gain, FCR, gut morphometry, it is observed that garlic supplementation was superior in comparison to ginger and mixture of garlic and ginger. Although ROFC was lower in ginger supplement group, it has significantly higher EPFI value as compared to other groups. Therefore, it is concluded that supplementation of garlic improves performance of broilers when added at the rate of $1 \%$ of broiler ration and can be a viable alternative to antibiotic growth promoter in the feeding of broiler chicken.

\section{Authors' Contributions}

HHS has conceptualized the aim of the study, designed and supervised the experiment. VKK executed the experiments and conducted statistical analyses. SSP, DDG and KSM has drafted, corrected and revised the manuscript. NKR and SJV have carried out laboratory analysis of feed samples. All authors read and approved indicating that they are collectively derived the final manuscript.

\section{Acknowledgments}

The authors acknowledge the facilities and financial support provided for the present study from Junagadh Agricultural University, Junagadh, Gujarat, India.

\section{Competing Interests}

The authors declare that they have no competing interests.

\section{References}

1. Asghar, A., Farooq, M., Mian, M.A. and Khurshid, A. (2000) Economics of broiler production of Mardan division. J. Rural Dev., 32(3): 56-65.

2. Borazjanizadeh, M., Eslami, M., Bojarpour, M., Chaji, M. and Fayazi, J. (2011) The effect of clove and oregano on economic value of broiler chickens diet under hot weather of Khuzesta. J. Anim. Vet. Adv., 10(2): 169-173.

3. Demir, E., Sarica, S., Ozcan, M.A. and Suicmez, M. (2003) The use of natural feed additives as alternatives for an antibiotic growth promoter in broiler diets. Br. J. Poult. Sci., 44: S44-S45.

4. Al-Amin, Z.M., Thomson, M., Al-Qattan, K.K., Peltonen Shalaby, R. and Ali, M. (2006) Anti-diabetic and hypolipidemic properties of ginger (Zingiber officinale) in streptozotocin induced diabetic rats. Br. J. Nutr., 96: 660-666.

5. Morakinyo, A.O., Akindele, A.J. and Ahmed, Z. (2011) 
Modulation of antioxidant enzymes and inflammatory cytokines: Possible mechanism of anti-diabetic effect of ginger extracts. Afr. J. Biomed. Res., 9: 195-202.

6. Hanieh, H., Narabara, K., Piao, M., Gerile, C., Abe, A. and Kondo, Y. (2010) Modulatory effects of two levels of dietary Alliums on immune responses. Anim. Sci. J., 81: 673-680.

7. Al-Shuwaili, M.A., Ibrahim, E.I. and Naqi Al-Bayati, M.T. (2015) Effect of dietary herbal plants supplement in turkey diet on performance and some blood biochemical parameters. Glob. J. Biosci. Biotechnol., 4(2): 153-157.

8. Issa, K. and Omar, J. (2012) Effect of garlic powder on performance and lipid profile of broilers. Open J. Anim. Sci., 2: $62-68$.

9. Oleforuh-Okoleh, V.U., Chukwu, G.C. and Adeolu, A.I. (2014) Effect of ground ginger and garlic on the growth performance, carcass quality and economics of production of broiler chickens. Glob. J. Biosci. Biotechnol., 3(3): 225-229.

10. Eltazi, M.A. (2014) Response of broiler chicks to diets containing different mixture levels of garlic and ginger powder as natural feed additives. Int. J. Pharm. Res. Allied Sci., 3(4): 27-35.

11. Bamidele, O. and Adejumo, I.O. (2012) Effect of garlic (Allium sativum L.) and ginger (Zingiber officinale Roscoe) mixtures on performance characteristics and cholesterol profile of growing pullets. Int. J. Poult. Sci., 11(3): 217-220.

12. Puvaca, N., Kostadinovic, L.J., Ljubojevic, D., Lukac, D., Popovic, S., Dokmanovc, B., and Stanacev, V.S. (2014) Effects of dietary garlic addition on productive performance and blood lipid profile of broiler chickens. Biotechnol. Anim. Husban., 30(4): 669-676.

13. Ram, B., Chinchorkar, S.S., Khardiwar, M.S. and Sayyad, F.G. (2015) A study of maximum and minimum temperatures trends at Junagadh (Saurashtra region) of Gujarat, India. Curr. World Environ., 10(1): 321-329.

14. BIS. (1992) Indian Standard: Poultry Feed Specifications. $4^{\text {th }}$ Revision. Bureau of Indian Standards, New Delhi.

15. Eyarefe, O.D., Emikpe, B.O. and Arowolo, F.O. (2008) Small bowel responses to enteral and glutamine administration following massive small bowel resection in rabbit. Afr. J. Med. Sci., 37: 309-314.

16. Wang, J.X. and Peng, K.M. (2008) Developmental morphology of the small intestine of African ostrich chicks. Poult. Sci. 87: 2629-2635.

17. Sharma, N. (2007) Effect of supplementation of enzymes on growth performance in commercial broilers. A Thesis Submitted to Anand Agricultural University. p49.

18. AOAC. (1995) Official Methods of Analysis. $16^{\text {th }}$ ed. Association of Official Analytical Chemists, Washington, DC.

19. Snedecor, G.W. and Cochran, W.G. (1994) Statistical Methods. $8^{\text {th }}$ ed. Oxford and IBH Publishing Co., New Delhi.

20. Herawati and Marjuki, (2011) The effect of feeding red ginger (Zingiber officinale rose) as phytobiotic on broiler slaughter weight and meat quality. Int. J. Poult. Sci., 10(12): 983-985.

21. Mohamed, A.B., Mohammed, A.M. and Ali Jalil Q. (2012) Effect of ginger (Zingiber officinale) on performance and blood serum parameters of broiler. Int. J. Poult. Sci., 11(2): 143-146.
22. Onu, P.N. (2010) Evaluation of two herbal spices as feed additives for finisher broilers. Biotechnol. Anim. Husb., 26(5-6): 383-392.

23. Aji, S.B., Ignatius, K., Ado, Y.A., Nuhu, J.B., Abdulkarim, A., Aliyu, U., Gambo, M.B., Ibrahim, M.A., Abubakar, H., Bukar, M.M., Imam, H.M. and Numan, P.T. (2011) Effects of feeding onion and garlic on some performance characteristics of broiler chickens. Res. J. Poult. Sci., 4(2): 22-27.

24. Rahimi, S., Teymouri, Z.Z., Karimi, T.M.A., Omidbaigi, R. and Rokni, H. (2011) Effect of the three herbal extracts on growth performance, immune system, blood factors and intestinal selected bacterial population in broiler chickens. J. Agric. Sci. Technol., 13: 527-539.

25. Cullen, S.P., Monahan, F.J., Callan, J.J. and O'doherty, J.V. (2005) The effect of dietary garlic and rosemary on grower-finisher pig performance and sensory characteristics of pork. Irish J. Agric. Food Res., 44: 57-67.

26. Tekeli, A., Kutlu, H.R. and Celik, L. (2011) Effects of $Z$. officinale and propolis extracts on the performance, carcass and some blood parameters of broiler chicks. Curr. Res. Poult. Sci., 1(1): 12-23.

27. Sadeghi, G.H., Karimi, A., Jahromi, S.P., Aziz, T. and Daneshmand, A. (2011) Effect of cinnamon, thyme and turmeric infusions on the performance and immune response in of 1 to 21 day-old male broilers. Braz. J. Poult. Sci., 14(1): $15-20$

28. Arshad, M., Kakar, A.H., Durrani, F.R., Akhtar, A., Sanaullah, S. and Niamatullah, M. (2012) Economical and immunological impact of ginger extract on broiler chicks. Pak. J. Sci., 64(1): 46-48.

29. Mansoub, N.H. and Nezhady, M.A.M. (2011) The effect of using thyme, garlic and nettle on performance, carcass quality and blood parameters. Ann. Biol. Res., 2(4): 315-320.

30. Ademola, S.G., Farimu, G.O. and Babatunde, G.M. (2009) Serum lipid, growth and haematological parameters of broilers fed garlic, ginger and their mixtures. World $J$. Agric. Sci., 5(1): 99-104.

31. Thayalini, K., Shanmugavelu, S., Saminathan, P.M., SitiMasidayu, M.S., Nor Idayusni, Y., Zainuddin, H., Nurul Akmal, C.A. and Wong, H.K. (2011) Effects of Cymbopogon citratus leaf and Zingiber officinale rhizome supplementation on growth performance, ileal morphology and lactic acid concentration in broilers. Malay. J. Anim. Sci., 14: 43-49.

32. Oladele, O.A., Emikpe, B.O. and Bakare, H. (2012) Effects of dietary garlic (Allium sativuml Linn.) supplementation on body weight and gut morphometry of commercial broilers. Int. J. Morphol., 30(1): 238-240.

33. Mohammed, A.A. and Yusuf, M. (2011) Evaluation of ginger (Zingiber officinale) as a feed additive in broiler diets. Livest. Res. Rural Dev., 23: Article ID: 202. Available from: http://www.lrrd.org/lrrd23/9/moha23202.htm. Retrieved on 04-11-2015.

34. Saiyed, M.A., Joshi, R.S., Savaliya, F.P., Patel, A.B., Mishra, R.K. and Bhagora, N.J. (2015) Study on inclusion of probiotic, prebiotic and its combination in broiler diet and their effect on carcass characteristics and economics of commercial broilers. Vet. World, 8: 225-231. 